\title{
LEEDS HOUSE OF RECOVERY
}

by

\author{
S. T. ANNING
}

IN THE years 1801 and 1802 an alarming epidemic fever spread in Leeds and the neighbourhood. The contagion extended so rapidly and proved so fatal that some hundreds were affected at the same time. ${ }^{1}$ Two doctors (one was Mr. Rusby) and several nurses fell victims to the disease. There was clearly need for a fever hospital in the town and Dr. Thorp* stated in 1831 that the matter had first been proposed by him in a letter to William Cookson Esq., then Mayor of Leeds. Dr. Thorp wrote that on 30 December 1801 in company with Mr. Rusby he visited ' 100 persons ill in fever after attending divine service, and before taking tea. ${ }^{2}$ Be that as it may, meetings had been held on 7 and 14 December 1801 at the Rotation Office, with Mr. Cookson in the Chair, to consider the best means of establishing a House of Recovery. ${ }^{3}$

The General Infirmary at Leeds did not admit patients with infectious diseases and the need for a special hospital for such persons was obvious. The treatment of patients with fever in separate wards or hospitals was an innovation. Special 'fever wards' were opened in the Chester Infirmary in $1783^{4}$ or $1784 .^{5}$ Two physicians at the Manchester Infirmary, Thomas Percival (1740-1804) and John Ferriar (1761-1815), had a number of fever wards ('houses of recovery' as they were euphemistically called) erected on ground belonging to the Infirmary in $1796 .{ }^{6}$ In 1802 the London Fever Hospital was founded.?

In the Leeds Intelligencer of 14 December 1801, which reported one of the meetings mentioned above, there is also a leading article advocating the establishment of a House of Recovery in Leeds in which it is mentioned that in Manchester, as the result of an institution of this kind, the number of fever-patients was reduced during the first year from 2,880 to 1,759 and there was a decrease of 400 burials during the same period (but we do not know whether there had been a decrease in other places without such an institution).

At the meeting reported on 14 December 1801 it was noted that a house had been found in Ebenezer Street (off Harewood Street, Ludgate Hill, Vicar Lane) as a temporary situation for the proposed House of Recovery but that a more convenient place was being sought. It was agreed that subscriptions should be solicited and a committee of management was appointed consisting of the Mayor (Mr. Cookson), William Thompson, John Goodman, John Broadhead, Mr. Calverley, Joseph Wood, Charles Brown and 'the Gentlemen of the Faculty'.

No further meeting appears to have taken place until early November $1802^{8}$ when the subscribers present were informed that 'it appears that the sum already subscribed was far short of the estimated expense of building'. However, in the Leeds Intelligencer of 6 December 1802 we learn that the subscriptions received were now over 965

* Robert Disney Thorp (1766-1849) was physician to the General Infirmary from 1800 to 1833. He was one of the founders of the Leeds School of Medicine and in 1830 was Mayor of Leeds. 


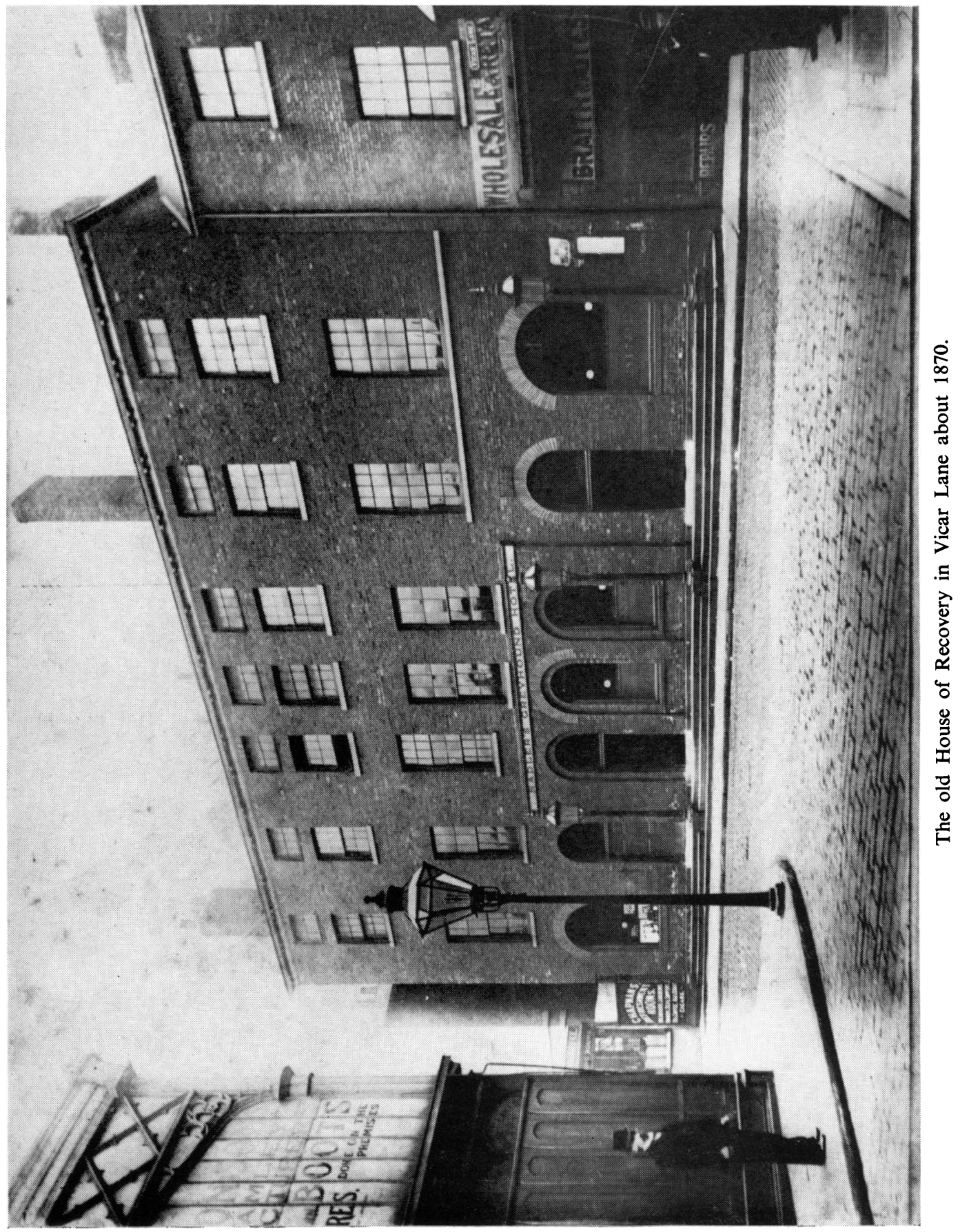




\section{Leeds House of Recovery}

guineas, and a week later that $£ 2611 s .8 d$. had been raised as the result of the performance of an Oratorio at the Ebenezer Chapel in the previous May. A notice about this had appeared: 'At the Ebenezer Chapel, Leeds on 3 May 1802 A grand selection of sacred music from the works of Handel for the benefit of the intended House of Recovery'. By 24 January 1803 the total of the subscriptions amounted to $£ 2,337$. Among those who supported the venture were Edward Baines, editor of the Leeds Mercury, John Marshall, the flax spinner, the Oates family and that of Beckett of the 'Old Bank'. ${ }^{9}$ (William Beckett Esq., M.P. was Treasurer in 1847.)

A site in Vicar Lane was chosen for the new hospital. It was opposite the Vicar of Leeds' house in a garden known as Vicar's Croft. At that time Vicar Lane was pleasant enough, though to the east the Quarry Hill area was built up and was soon to become one of the worst slums in the country and a breeding ground of disease. The site of the House of Recovery was well chosen for this reason..$^{10}$

The site was held on lease from the Committee of Pious Uses, a body set up in the seventeenth century to administer the charities of the town. The rent was $£ 2310$ s. $6 d$. per annum. The leases were normally granted for a period of twenty-five years and could be renewed, though at a higher rate. The annual income from property in Leeds and funded stock belonging to the Pious Uses Trust in 1830 totalled $£ 2,76110$ s. $10 \mathrm{~d}$. of which $£ 1,67417 \mathrm{~s}$. $6 \mathrm{~d}$. went to the free grammar school. The rest was used for various purposes including the provision of clothing for the poor of the parish and the repair of roads. ${ }^{11}$

Evidently building of the new hospital was proceeded with, for the Leeds Intelligencer of 20 August 1804 reported a general meeting of subscribers at which it was unanimously resolved that part only be opened with ten beds together with furniture provided for the committee room, the housekeeper's room and the apothecary's shop. Special thanks were given to Dr. Thorp and it was agreed that the establishment should consist of one apothecary, one head-nurse and one under-nurse. In September advertisements were inserted in the press for these appointments, the salary for the head-nurse to be fifteen guineas and that for the under-nurse ten guineas per annum. Both these 'ladies to be single women or widows without family'.12

In October 1804 officers were elected; Drs. Thorp, Hird* and Baynes as physicians, Messrs Logan,** William Hey Jr. $†$ and Chorleyt† as surgeons, and John Moxon as inspector. ${ }^{13}$ At a special general board meeting in the same month it was agreed to open the house for patients 'labouring under infectious fevers' on 1 November 1804. The intention was 'to prevent the spread of contagious fevers by removing into wellventilated apartments every poor person on the first appearance of an infectious fever, by which separation the rest of the family and neighbourhood will be preserved from its ravages'. ${ }^{14}$

In the original rules of the hospital we read that:

* Benjamin Hird, M.D. (1763-1831) was a physician at the General Infirmary at Leeds from 1790 to 1819 .

** Maurice Logan (c. 1840) was surgeon at the Infirmary from 1786 to 1812.

t William Hey, F.R.C.S. (1772-1844) was the second son of William Hey, F.R.S., one of the founders of the Infirmary in 1767. He was surgeon at the Infirmary from 1812 to 1830 . Twice mayor of Leeds, he published in $1815 \mathrm{~A}$ Treatise on the Puerperal Fever.

$\mathrm{Ht}$ Thomas Chorley, whose dates of birth and death have not been determined, was surgeon at the Infirmary from 1794 to 1833. 


\section{S. T. Anning}

All persons labouring under infectious fevers who are unable to provide medicines, or proper accommodation for themselves, and residing within the following districts of Leeds, Hunslet, Holbeck, Headingley, Chapeltown, and Potternewton are admissible.

Domestic servants may be admitted, upon payment of a weekly sum of not more than one guinea, at the discretion of the weekly board.

All patients dismissed from the House of Recovery shall be enjoined to attend in person or by their friends, at the monthly board next after their dismissal.

A medical inspector shall be chosen by a general board who shall also appoint his salary. His office shall be to recommend and personally see to the execution of such means of preventing the spreading of infection in the families, whence any sick person has been admitted into the House of Recovery as the physicians of the charity shall direct.

The Apothecary shall attend the House daily, shall compound the medicines . . . in the absence of the physicians receive patients whose cases do not admit of delay. ${ }^{16}$

The duty of the inspector was to detect 'the first appearance of infection, to cause the removal of the patient to the house of recovery, and to superintend the fumigating and white-washing of the apartment from which he is removed. So great is the solicitude of the physicians to promote early removal, that rewards are offered to such as shall first give information of an infectious fever in their neighbourhoods.'16

Later the rules were modified. We do not know when, but it was probably after the Apothecaries' Act of 1815, though the first annual report seen containing them is that of 1860. In them it states that the 'Resident Apothecary' shall be a Licentiate of the Society of Apothecaries in London and shall also be Secretary attending all Board and Committee meetings. Another change was in regard to the admission of domestic servants who were to be charged one shilling and ninepence a day.

The first Apothecary (later known as resident medical officer) was Thomas Teale who was appointed in October 1804. ${ }^{17}$ One of his duties was vaccination and a month previously there had been an advertisement in the local papers that the children of indigent parents could be vaccinated without fee at the hospital.

From the opening of the hospital on 2 November 1804 until the end of the year eleven patients were admitted of whom eight were discharged, so that on 31 December 'three remain under care'. ${ }^{18}$ The patients were admitted at all times on giving two hours' notice and on every Thursday from three to four p.m. ${ }^{19}$ By 30 October 1805 , when the hospital had been open for one year 77 patients had been admitted of whom 63 were discharged cured, seven died, one was 'rejected as improper' and six remained on the books. Only 492 individuals had availed themselves of free inoculation for cow-pox during the year. ${ }^{20}$

By the early 1840s it was appreciated that the hospital in Vicar Lane was too close to the areas in which various infectious diseases were endemic ${ }^{21}$ and in 1844 the Committee of Pious Uses decided to increase the rent from $£ 2310 s$. $6 d$. to $£ 120$ a year. As Mayhall reported:22

... a meeting of the subscribers and benefactors to the charity [the House of Recovery], was held in the Philosophical Hall, when it was decided to present a requisition to the mayor, to convene a public meeting of the inhabitants, for the purpose of considering the expediency of erecting a new House of Recovery. A committee was formed, and a subscription opened, and on the 4th July following [1844], it was determined to purchase not less than two acres of land as a site for the building, of Mr. Arthur Lupton, Junr., of Headingley, situated in Beckettstreet, Burmantofts. The building was opened in 1846, having cost about $£ 7,000$. It stands on an elevated site, and is sixty yards back from the road, within an enclosure of about $2 \frac{1}{2}$ acres, which is laid out in gardens. The enclosure has a frontage of about 117 yards to the road, from 


\section{Leeds House of Recovery}

which it is separated by a low wall, surmounted with high iron palisading, and runs backwards 111 yards. The building is of brick, with a stone portico; its length is 253 feet, by 23 feet 6 inches wide. There are 22 wards, calculated to accommodate 130 patients. Baths are provided, with an ample supply of hot and cold water through the house. The establishment is well ventilated, and warmed on an improved principle. This valuable institution is supported by annual subscriptions, voluntary donations, and collections at different places of worship. There are 80 beds, with room for 20 more.

From the Ordnance Survey Map of 1850 (surveyed in 1847) we see that, with the exception of the cemetery, the new House of Recovery was then the only occupant of Beckett Street, soon to be extensively developed. The old hospital in Vicar Lane passed into the hands of Joseph Clay and became the Greyhound Hotel (fig. 1). The premises were demolished in 1938 and on the site is now a branch of the Midland Bank. ${ }^{23}$

We have only fragmentary information about the institution prior to 1860 as no annual reports have been discovered before that year. Recently a number of the annual reports were found in a box in the General Infirmary at Leeds. These have been added to the reports in the Reference Library and together they almost completely cover the years from 1860 .

An innovation which took place in 1869 was the opening of a convalescent home for patients discharged from the House of Recovery. From 1867 patients from the Infirmary were sent to convalescent institutions at Ilkley, Scarborough and Southport, and from 1869 to the 'Convalescent Hospital at Burmantofts' in Leeds. From 1870 the hospital at Cookridge near Leeds was used. But the patients from the House of Recovery were not accepted by these institutions.

By the efforts of Mr. Darnton Lupton and the Rev. Edward Jackson a convalescent home was established in Pontefract Lane, Leeds, for 'fever patients'. It was referred to in the annual report for 1878 as 'an extremely valuable appendage to the Hospital'.

The first additional building on the Beckett Street site appears to have been a lodge built near the gates in 1873 at a cost of about $£ 700$. In the following year an additional wing to the main building was completed. The new building was occupied by the resident medical officer, the matron and the domestic servants. The rooms vacated by these individuals were then taken over by the nurses and some were used for additional storerooms and offices. In addition, states the annual report of 1874: 'The arrangement of the main drains has been altered and much improved... . The complete separation of the new wing from the main building is obviously a great advantage with regard to the safety and comfort of the resident staff of officials, and the direct communication with the kitchens and wash-houses facilitates the superintendence of these departments'.

The annual report of 1872 noted that for a long time past an increase of accommodation for the nurses was required and it was as a result of the bequest of Mrs. Thomas Tennant of $£ 3,000$ in 1872 that this was achieved.

We have little information about the nurses, but when Sir Clifford Allbutt* was

* Thomas Clifford Allbutt (1836-1925) was born at Thornhill, Dewsbury, near Leeds, the only son of the Rev. Thomas Allbutt. In 1861 he was appointed physician to the House of Recovery and in 1864 physician to the General Infirmary at Leeds. In 1892 he became Regius Professor of Physic at Cambridge and remained so for the rest of his life. He was an eminent physician and a Fellow of the Royal Society. 


\section{S. T. Anning}

opening a home for nurses at Dewsbury on 19 October 1909 he described the nursing and nurses of more than forty years before at the House of Recovery. He said that there were two wards, one for men, the other for women, each with forty beds, under the charge of three nurses, two for the day and one for the night work. 'They were great, powerful, red-faced women, who all ate a great deal of beef and drank a great deal of beer, and lifted the patients as you would lift puppy dogs. ${ }^{24}$ Some sixteen years after he began work at the Leeds House of Recovery Allbutt wrote:

When I was first called to the charge of medical wards nothing startled me more than the frequent deaths of patients from fevers and acute diseases, who, to a young observer, seemed likely to recover. A close perusal of the dead body gradually convinced me that such deaths are due not so much to the arrest of the part attacked or to the intensity of the poison as to some pre-existing diminution of the factor of safety. ${ }^{25}$

It is probable that malnutrition was playing a part.

In 1865-6 there was an epidemic of typhus fever in Leeds and Allbutt treated a number of patients in the House of Recovery with much success by open-air methods, being supported in this, at that time rather revolutionary form of treatment about which little was known, by hearing that in Ireland many victims of this disease 'laid out on the roadsides to die, unexpectedly recovered, to the great discomfiture of their heirs-at-law' ${ }^{26}$

In the seventy-fourth annual report (1878) which was read at the annual general meeting by Dr. Churton, ${ }^{*}$ we hear for the first time of the possibility of the hospital being taken over by the corporation of the township of Leeds. Dr. Churton first mentioned the financial difficulties of the institution. He pointed out that with regard to fever epidemics a good year for the town was a bad year for the hospital from a financial point of view. Subscriptions tended to fall and the payments from the various Boards of Guardians and from non-union patients dropped greatly. He continued:

Matters continung thus, a few more good years and the hospital is ruined. Surely this ought not to be. It cannot fail to be noted how small a sum [ $£ 49$ in 1878] has been received from private patients (i.e. those not paid for by the Guardians). Very few such patients are admitted, in fact; yet many cases of typhoid and other fevers exist amongst not very poor people in the town, and it can scarcely be doubted that in some of them it would be greatly to the interest of everybody concerned in attendance upon them that they should be sent into the Fever Hospital. Now, it is understood that the sanitary officers have power to compel any person having fever, who cannot be properly treated at home, to be sent to a fever hospital at his own cost, or at the cost of his friends. With a view to the more easy and effectual carrying out of this salutary law, a proposition was made by the Sanitary Committee, last July [1878], to take over the House of Recovery, and to convert it into a Fever and Small-Pox Hospital, under the control and at the expense of the Corporation of the town of Leeds. The Committee of the Hospital, however, found two difficulties in the way of accepting this offer: (1) The honorary medical staff were unanimously opposed to the plan of having small-pox and other fever patients under the same roof or in the immediate vicinity of each other, and therefore demurred to the proposition in that form; and (2) there were certain legal difficulties (not, however, insurmountable) connected with the proposed transfer. Nevertheless, the Committee were, and remain, very willing and anxious to consider the proposition, and to agree to it if it should be for the greater good of the town. The Sanitary Committee has, however, for the present let the matter drop.

* Thomas Churton (1839-1926) was physician to the House of Recovery from 1878 to 1885 and to the Infirmary from 1880 to 1919. 


\section{Leeds House of Recovery}

Nevertheless, in the next annual report (1879) it is stated that a deputation from the hospital had met the Sanitary Committee and had been informed that the Committee had the power to pay for patients in the hospital without being compelled by law to recover such payment from the patient's friends, a point upon which there had previously been some misconception. The income of the hospital in $1879(£ 2,125)$ had been derived from subscriptions and funded property ( $£ 775)$, from casual benefactions, including $£ 134$ from the Hospital Sunday Fund ( $£ 264)$, from private patients (£104), and from the Guardians of the various unions in and about Leeds (£982). It was made clear that the regular income of the hospital would do little more than pay the salaries, wages and 'incidental' expenses. Some payment made by or on behalf of the patients was essential but it was also made clear that any person whatsoever with an infectious fever, other than smallpox, would be admitted immediately. Only after admission would the question of payment privately, by the Guardians or by the Sanitary Committee be considered. Even were there any dispute about such payment the stay of the patient in hospital would not be shortened.

Although 1879 ended with the year's accounts balanced the hospital remained in debt. Fortunately this could be paid off in 1880 as a result of a bequest of $£ 2,98716$ s. 11 d. from the estate of Miss Caroline Brown, formerly of Leeds, and of a sum of $£ 250$ from the profits of the Leeds Musical Festival. There was even a 'certain sum' in hand for investment and for 'much needed renovation of certain parts of the fabric of the Hospital together with some internal fittings and in making certain alterations in the drainage system considered necessary by the Local Government Board'.

This was all most satisfactory but the more general state of affairs was not, as we see from an extract from the report of Dr. Thorne, the medical officer of the Local Government Board, on Fever Hospitals. The extract quoted in the annual report of the House of Recovery for 1882 referring to that hospital reads:

Considering the total number of admissions of cases of scarlet fever during the years 1878-1879 amounted to 125, while the deaths from that disease in the Borough during those years were 534 (corresponding probably to about 5,000 patients), it is obvious that the Hospital does not fulfil its function as a means of isolation to any adequate degree. And lately, while the report of the Medical Officer of Health for last December shows a mortality from scarlet fever alone of 35 (probably corresponding to 350 cases), the House of Recovery received only nine cases of scarlet fever during that month.

However, in 1884 the situation improved and 'owing to the greater vigilance of the Sanitary Authorities in the isolation of infectious diseases, the number of patients admitted rose last year [1884] to 381' according to the annual report which contains an important statement:

Financially, the Hospital has been conducted during the past year on a somewhat different basis than heretofore. Instead of a fixed sum per head being charged to Sanitary Authorities, and the deficit made up out of subscriptions, the subscription-list has been in abeyance, and the various Authorities sending patients have been charged the exact cost of their maintenance. This has allowed of the funds from endowments, etc., in the hands of the Committee, being devoted to cases of charity, and more than $£ 250$ has been thus expended on patients in the Hospital and in Convalescent Homes. The Committee have great pleasure in announcing that the negotiations referred to in last year's Report, carried on with a view to the transfer of the House 


\section{S. T. Anning}

of Recovery to the Urban Sanitary Authority are, at last, nearly completed; and in a few weeks they hope to be able to arrange for the legal transfer of the building, and the preparation of a scheme by which the funds remaining in their hands, and those accruing from the sale of the Hospital, will be devoted to objects of charity of a kindred kind.

The Corporation of Leeds bought the hospital building for $£ 6,000$ and took control from 1 July 1885 . Since its opening in 1846 no fewer than 13,011 patients had beenfadmitted to this building and 25,000 since the opening of the Leeds House of Recovery in 1804. The numbers admitted annually varied greatly, the largest being 1,018 in 1865. Seacroft Hospital, on the outskirts of Leeds, built by the Corporation in three phases during the years 1893-1904, took the place of the hospital for infectious disease in Beckett Street which was demolished for housing developments.

The funds of the House of Recovery were used to found a convalescent home at Gildersome, near Leeds. From 1886 the annual reports were those of 'The Leeds House of Recovery and Convalescent Home, Gildersome'. This charity continued into the early years of this century but at a meeting of the Board of the General Infirmary at Leeds on 29 September 1905 it was stated that the funds of the Leeds House of Recovery were to be divided between the Infirmary $(£ 16,000)$, the Public Dispensary $(£ 6,000)$, the Women and Children's Hospital $(£ 2,000)$ and the Leeds Tuberculosis Association ( $£ 2,000)$. However, as far as the Infirmary was concerned the outcome was not so satisfactory for in the minutes of the Weekly Board held on 2 August 1907 we read that the Infirmary acquired 58 per cent of the investments of the House of Recovery, equivalent to a sum of $£ 11,800$.

\section{NOTES ON SOME EPIDEMICS IN LEEDS}

\section{TYPHUS}

Typhus or 'Gaol Fever' is spread by lice and is endemic in areas of overcrowding and poverty. In Leeds in 1847 'it prevailed to an alarming extent, especially in the eastern part of the town' where there was appalling overcrowding in the worst of slum property. ${ }^{27}$ There was a large Irish population and the outbreak of typhus 'followed in the track of the Irish Famine Fever, whose worst results . . . were due rather to the neglect of the British Government than to the hand of God' according to a priest. ${ }^{28}$

Mayhall wrote:29

On the 18th of this month [June 1847] it was reported that in the Rose and Crown-yard, Unionstreet, twenty-eight persons had the fever in seven houses, three of which were without beds; in Wellington-yard ten in seven houses, and in Goulden's-buildings four in three houses were attacked. In one house in Brighton-court, in which there was not a single bed, twelve had the fever, and in a house in Brook-street six were attacked under similar distressing circumstances. In three houses in Brussels-street twenty persons had the fever, and in a single house in Baptistcourt no less than eleven had it. . In the whole township there were at least 400 persons suffering from the disease.

At the Leeds House of Recovery, according to Allbutt, 'where both typhus and typhoid were abundant, my senior colleagues, to a man, scouted my assertion of the differences.' This was in a letter to Dr. Garrison..$^{30}$ This is surprising for William W. Gerhard (1809-72) of Philadelphia in 1837 had clearly distinguished between the 


\section{Leeds House of Recovery}

two diseases. ${ }^{31}$ In 1865-66 there was an epidemic of typhus in Leeds and during the seven months, 11 October 1865 to 30 April 1866, 626 patients with this fever were admitted to the House of Recovery where several house physicians died from it. Allbutt used open-air treatment. ${ }^{32}$ In 1871 the House of Recovery admitted 106 patients and in 1874162 patients with typhus. In most years during this period the number was about 20 to 30 declining from 1882 to none in 1883 and five in 1885 .

\section{RELAPSING FEVER}

Like typhus fever, relapsing fever is louse-borne, and is the result of infection from Treponema recurrentis. As regards the House of Recovery its incidence among the patients admitted declined earlier than with typhus fever. In 1870 no less than 353 patients were admitted with this disease, but in 1871 only 25 (none after May), and in 1872 only 23 . Thereafter no patients with this fever were admitted.

\section{CHOLERA}

There was a serious epidemic of cholera in Leeds in 1832, when there were 1817 cases and 702 deaths. ${ }^{33}$ Of previous epidemics in Leeds we have little information but there had been one in $1825 .^{34}$ The epidemic of 1832 appears to have been related to the import of rags from Russia, Prussia and the Hanseatic ports whence many ships came to Hull. At that time there was much cholera in Northern Europe. The rags were of two kinds; one for the manufacture of paper and the other, rags from continental hospitals, used for the manuring of 'hop-gardens'. ${ }^{35}$ These were presumably foul. A case of cholera was reported in Hull in July 1831 and a month later there was an epidemic in Sunderland. In December 1831 William Hey* and Samuel Smith** visited Sunderland and were convinced that the disease there was 'Asiatic cholera'. It spread to Newcastle (January 1832), Scotland a month later, and after another two weeks was in London. ${ }^{36}$

The House of Recovery had inadequate accommodation and too small a staff to deal with the epidemic in Leeds. Although as many cholera patients as possible were admitted the majority were treated in temporary and makeshift buildings, among them empty factories. ${ }^{37}$ The establishment of a cholera hospital in St. Peter's Square, near the Parish Church gave great dissatisfaction to the inhabitants and owners of property in the neighbourhood, who manifested their feelings by breaking the windows of the hospital. ${ }^{38}$

Although at that time the spread of cholera by polluted drinking water was not appreciated, a map drawn by Robert Baker $\dagger$ plotting the incidence of the disease showed its relationship to the many small streams or becks which intersected the town and flowed to the river Aire. ${ }^{39}$ Leeds had no drainage system other than a few short drains leading into the river. Conditions in the slums were appalling. Robert

\footnotetext{
* William Hey (the third), F.R.C.S. (1796-1875) was elected surgeon to the Infirmary in 1830. He was one of the founders of the Leeds Medical School in 1831 and was one of the surgeons on the staff of the House of Recovery.

** Samuel Smith, F.R.C.S. (1790-1867) was also one of the founders of the Leeds Medical School and was surgeon to the Infirmary from 1819 to 1864.

t Robert Baker (1803-80) became in 1825 the Poor Law Medical Officer for Leeds and in 1833 , in the report of the Leeds Board of Health, published a 'Cholera plan of Leeds' showing the distribution of cholera during the epidemic of 1832, to emphasize the prevalence of the disease near open sewers and becks. In 1834 he became an Inspector of Factories.
} 


\section{S. T. Anning}

Baker, in his report to Edwin Chadwick stated:40

The river Aire, which courses about a mile and a half through the town is liable suddenly to overflow from violent or continued rains, or from the sudden thawing of heavy falls of snow. The lower parts and dwellings, both in its vicinity and in that of the becks, are not unfrequently therefore inundated; and as the depth of the cellars is below the means of drainage, the water has to be pumped out by hand-pumps on to the surface of the streets. In those parts of the town, and particularly where the humbler classes reside, during these inundations, and where there are small sewers, the water rises through them into the cellars, creating miasmatic exhalations, and leaving offensive refuse, exceedingly prejudicial to the health as well as to the comfort of the inhabitants.

He continued:41

In one cul-de-sac, in the town of Leeds, there are 34 houses, and in ordinary times, there dwell in these houses 340 persons, or ten to every house; but as these houses are many of them receiving houses for itinerent labourers, during the periods of hay-time and harvest and the fairs, at least twice that number are then here congregated. The name of this place is the Boot and Shoe-yard, in Kirkgate, a location from whence the Commissioners removed, in the days of the cholera, 75 cart-loads of manure, which had been untouched for years, and where there now exists a surface of human excrement of very considerable extent, to which these impure and unventilated dwellings are additionally exposed. This property is said to pay the best annual interest of any cottage property in the borough.

\section{Baker adds:42}

. . . there are streets, elevated a foot, sometimes two, above the level of the causeway, by the accumulation of years, and stagnant puddles here and there, with their foetid exhalations, causeways broken and dangerous, ash-places choked up with filth, and excrementious deposits on all sides as a consequence, undrained, unpaved, unventilated, uncared-for by any authority, but the landlord, who weekly collects his miserable rents from his miserable tenants.

One result of Baker's work was a meeting held in January 1833 of the medical men of Leeds at which the following resolution, signed by all (eight physicians and thirty-eight surgeons), was passed $:^{43}$

That we, whose names are undersigned, are of the opinion that the streets in which malignant cholera prevailed most severely were those in which the drainage was most imperfect; and that the state of general health of the inhabitants would be greatly improved, and the probability of a future visitation from such malignant epidemics diminished, by a general and efficient system of drainage, sewerage and paving, and the enforcing of better regulations as to the cleanliness of the streets.

However, it required another epidemic of cholera in Leeds in 1849,44 once again originating in Hull, to stimulate the town into action though in 1842 the Leeds Improvement Act had been passed which gave authority to the Town Council to lay sewers, level and pave the streets, and prohibited the occupation of houses in courtyards narrower than thirty feet. ${ }^{45}$ In 1850 work on a sewerage scheme was started and completed in 1855.66 In February and March 1854 there had been 40 cases of cholera and 15 deaths. ${ }^{47}$

We do not know when the last patient with cholera was admitted to the House of Recovery but none is recorded in the annual reports from 1860 onwards.

\section{TYPHOID FEVER}

Typhoid or enteric fever, which is also spread by contaminated water, continued 


\section{Leeds House of Recovery}

to appear in Leeds after the sewers were completed. No doubt there were many carriers of the disease. In the latter period of the House of Recovery, excluding 1885 when there were 31 patients with typhoid in the first six months before closure, during the fifteen years 1870-84 the numbers per annum varied between 33 and 225 (mean 101).

\section{SCARLET FEVER}

The incidence of scarlet fever among the patients of the House of Recovery was very variable. In the fifteen years 1870-84 1,021 patients were admitted with this disease. The mean per annum was 68 but the range was wide. In 1872 there were only two but in 1876 there were 105, in 1883191 , with 45 deaths, and in 1884 there were 208 .

\section{SMALLPOX}

As already mentioned, from the time of opening, free vaccination was carried out at the House of Recovery but the response was poor. Referring to the year 1850 Mayhall reported 'March 4. At this time the smallpox was prevalent in almost all parts of Leeds; no doubt caused by the great neglect of vaccination. ${ }^{48}$

Smallpox patients were admitted to the House of Recovery for many years. In the annual report for $1862-3$ we find that 138 patients had been admitted, and read that:

The number of smallpox cases admitted since the last Report is exactly equal to the whole number of such cases admitted during the previous fifteen years. Of these, 73 were distinctly vaccinated cases, and only two were fatal. Of the 65 unvaccinated cases 14 died; of the 10 uncertain cases all escaped, warranting the conclusion that the majority at least had really been vaccinated.

The epidemics continued until mid-1864 and occasional patients were admitted. There were 15 in 1870 and as many as 118 in 1871 . In the report for this year we read:

The necessity of isolating all cases of smallpox as completely as possible was dwelt on in last year's report, and further experience has only served to strengthen the opinion then expressed. The Committee have great pleasure in expressing their appreciation of the far-seeing liberality with which the Guardians of the Poor for the Leeds Union have repaired and furnished the sheds now standing on their land near the Workhouse, and the readiness with which they were granted for the reception of smallpox patients.

In 1872 the Corporation agreed to isolate and care for all patients with smallpox and the 33 patients admitted with this disease to the House of Recovery were transferred to the Smallpox Hospital. In 1873 the last smallpox patients ever to be admitted, two in number, were promptly removed to this hospital.

\section{ACKNOWLEDGEMENTS}

It is with gratitude that I acknowledge the help of Mr. Frank Beckwith, librarian of the Leeds Library, the staff of the Reference Library, Leeds and Mr. C. M. Mitchell, Curator of the Leeds Museum, who provided the photograph.

\section{REFERENCES}

1. WhitTAKer, T. D., Loidis and Elmete, Leeds, Robinson \& Holdsworth; Wakefield, Hurst, 1816, p. 85. 


\section{S. T. Anning}

2. Leeds Intelligencer, 2 January 1831.

3. Leeds Intelligencer, 14 December 1801.

4. Ibid.

5. SHRYOCK, R. H., The Development of Modern Medicine, London, Gollancz, 1948, p. 179.

6. Singer, Charles, and Underwood, E. Ashworth., A Short History of Medicine, Oxford, Clarendon Press, 1962, 2nd ed., p. 189.

7. Dainton, Courtney., The Story of England's Hospitals, London, Museum Press, 1961, p. 94.

8. Leeds Intelligencer, 8 November 1802.

9. Leeds Reference Library, personal communication.

10. Ibid.

11. MaYhall, John, The Annals of Yorkshire, Leeds, Johnson, 1861, p. 365.

12. Leeds Intelligencer, 3 September 1804.

13. Leeds Intelligencer, 20 October 1804.

14. Mattison, Alf, 2 September 1938, unpublished. Leeds Reference Library.

15. [RYLEY, JoHN], The Leeds Guide 1806, Leeds, Edward Baines, 1806, p. 46.

16. WhITTAKER, T. D., op. cit., p. 85.

17. Leeds Intelligencer, 29 October 1804.

18. Leeds Intelligencer, 7 January 1805.

19. The Leeds Directory for 1809, Leeds, Baines, 1809, p. 17.

20. Leeds Intelligencer, 16 November 1805.

21. Leeds Reference Library, personal communication.

22. Mayhall, John, op. cit., p. 500.

23. Leeds Reference Library, personal communication.

24. Rolleston, Sir Humphry Davy, The Right Honourable Sir Thomas Clifford Allbutt, London, Macmillan, 1929, p. 21.

25. Ibid., p. 22.

26. Ibid., p. 32.

27. MaYhall, JoHN, op. cit., pp. 542-3.

28. Waugh, Norman, A Short History of St. Anne's Cathedral and the Leeds Missions, London, Art and Book Company, 1904, p. 40.

29. Mayhall, John, op. cit., p. 543.

30. Rolleston, Sir Humphry Davy, op. cit., p. 18.

31. Major, Ralph H., A History of Medicine, Oxford, Blackwell, 1954, vol. II, p. 759.

32. Rolleston, Sir Humphry Davy, op. cit., pp. 32-4.

33. MaYhall, John, op. cit., p. 388.

34. MeIKLejoHn, A., The Life, Work and Times of Charles Turner Thackrah, Surgeon and Apothecary of Leeds (1795-1833), Edinburgh and London, Livingstone, 1957, p. 33.

35. Leeds Intelligencer, 9 June 1831.

36. Leeds Intelligencer, 16 February 1832.

37. Leeds Reference Library, personal communication.

38. MaYhall, John, op. cit., p. 389.

39. BONSER, K. J., and Nichols, H., Printed Maps and Plans of Leeds, 1711-1900, Leeds, Publications of the Thoresby Society, 1960, vol. XLVII, No. 100.

40. Chadwick, Edwin, The Sanitary Condition of the Labouring Population of Gt. Britain, 1842, ed. M. W. Flinn, Edinburgh, University Press, 1965, p. 113.

41. Ibid., p. 114.

42. Ibid., p. 200.

43. Leeds and its History, Tercentenary Supplement of the Yorkshire Post, 1926, p. 104.

44. Mayhall, John, op. cit., p. 576.

45. Leeds and its History, op. cit., p. 105.

46. Ibid., p. 108.

47. Mayhall, John, op. cit., p. 646.

48. Ibid., p. 585. 